Extrême-Orient Extrême-Occident

\section{Extrême-Orient Extrême-Occident}

$37 \mid 2014$

Penser les épidémies depuis la Chine, le Japon et la Corée

\title{
Jean-Jacques Matignon's Legacy on Russian Plague Research in North-East China and Inner Asia (1898-1910)
}

L'héritage de Jean-Jacques Matignon dans les recherches russes sur la peste dans le Nord-Est de la Chine et l'Asie centrale (1898-1910)

馬丁榮(Jean-Jacques Matignon) 的鼠疫來源假説及其對俄國在中國東北 和内亞鼠疫研究(1898-1910) 的影響

\section{Christos Lynteris}

\section{OpenEdition}

\section{Journals}

Electronic version

URL: http://journals.openedition.org/extremeorient/331

DOI: 10.4000/extremeorient.331

ISSN: 2108-7105

\section{Publisher}

Presses universitaires de Vincennes

\section{Printed version}

Date of publication: 1 September 2014

Number of pages: 61-89

ISBN: 978-2-84292-411-9

ISSN: 0754-5010

\section{Electronic reference}

Christos Lynteris, « Jean-Jacques Matignon's Legacy on Russian Plague Research in North-East China and Inner Asia (1898-1910) », Extrême-Orient Extrême-Occident [Online], 37 | 2014, Online since 01 September 2017, connection on 19 April 2019. URL : http://journals.openedition.org/ extremeorient/331 ; DOI : 10.4000/extremeorient.331 


\title{
Jean-Jacques Matignon's Legacy on Russian Plague Research in North-East China and Inner Asia (1898-1910)
}

\author{
Christos Lynteris
}

Medical historical research on plague (Yersinia pestis) in Northeast China, or, to use the ethno-historically more relevant term, Manchuria, has witnessed a recent revival with many articles and one monograph published on the subject in the last ten years. ${ }^{1}$ All scholarly publications so far, including the ones by the author of this paper, have focused on the Manchurian plague epidemic of 1910-1911, a choice justified by the magnitude of the outbreak as a biopolitical and geopolitical event in the region. As a result, when it comes to examining perceptions of the cause of plague in Manchuria, historical research has focused on the zoonotic origins of the disease as propagated by $\mathrm{Wu}$ Liande, the leading Chinese epidemiologist at the time. ${ }^{2}$ However Wu's writings on the subject were the final, and in many ways definitive, form of a long research trajectory that was initiated from across the Sino-Russian border in the 1890s. The zoonotic origin of plague in the region was problematised as early as 1894 in the work of Russian medical researchers operating in Transbaikalia. ${ }^{3}$ They argued that the main vector of plague was the Siberian marmot, or so-called tarbagan; a large rodent hunted by native Mongols and Buryats for its fat, fur and meat. The pioneer of these studies was Mikhail Edouardovich Beliavsky, a senior doctor at the military hospital of Aksha, a Russian post north of the border trade hub of Kyakhta. Examining a limited outbreak of bubonic plague in the autumn of 1894, Beliavsky came to the daring conclusion that tarbagans were carriers of plague and that the disease spread to humans whilst skinning or cutting the animal. ${ }^{4}$ His tarbagan hypothesis, articulated five years

1. Gamsa 2006; Sean 2011; Knab 2011; Summers 2012; Lynteris 2013.

2. See the transcripts of the First International Plague Conference: Strong 1912.

3. Transbaikalia refers to the Russian territories east and south of Lake Baikal, currently divided into the Republic of Buryatia and Zabaykalsky Krai.

4. Beliavsky 1895 . 
before Paul-Louis Simond's celebrated paper on rats, was the first researchbased theory to support the involvement of an animal vector in the spread of plague. As such it would exercise great influence on plague researchers and epidemiologists in the decades to come, with Wu's verdict that marmots were the origin of the Manchurian plague outbreak of 1910-1911 (as expressed in the First International Plague Conference, April 1911, Mukden) being a definitive step towards its international endorsement. ${ }^{5}$

All in all, there is no doubt that the problem of the zoonotic origins of plague in the region is the most pertinent question when it comes to the historical analysis of plague related theories and policies in Northeast China and Inner Asia at large. However, this justified focus on the problem of zoonosis has left in the shadow of historical and anthropological analysis other contemporary trends in epidemiological thought regarding plague in the region. A major theme in this respect, which I wish to explore in this paper, was the problematisation of the locus and the trans-regional directionality of the disease, as developed in the period between Beliavsky's founding plague research in the region, and Wu Liande's world-renowned oeuvre following the Manchurian pneumonic plague of 1910-1911.

As Marta Hanson has demonstrated in her ground-breaking work, at the turn of the century the "geographic imagination" of disease played a crucial role in the constitution of both colonial and Imperial Chinese perceptions of what from a biomedical perspective we consider as epidemics. ${ }^{6}$ In the case of the Sino-Russian border area, prior to the 1910-1911 outbreak, the geographic problematisation of plague lay squarely in the hands of non-Chinese medical experts and explorers who contended for the explanation of three vital and interlinked (even overlapping) questions: a) where plague came from; b) in which areas was plague endemic; c) what was the direction of the spread of plague and why. It was evidently hoped that the elucidation of these questions could provide an understanding of plague in Northeast China and Inner Asia, compatible in its logic and language to the understanding of plague outbreaks in other places of the world at the time. ${ }^{7}$ This paper will examine attempts

5. It should, however, be noted that after Wu's "reversal of verdicts" on the tarbagan hypothesis in his May 1913 Journal of Hygiene article, it would take another eight years until the full canonisation of the hypothesis, following Wu's embarrassing reendorsement in the aftermath of the second Manchurian plague outbreak (1920-1921).

6. Hanson 2011.

7. Before 1910 with exception of San Francisco, no major outbreak of plague had occurred north of the 40th parallel, whereas in the South the disease had ravaged Yunnan, Hong Kong, India, Australia, South and West Africa, parts of Latin America 
to generate such a geographic epidemio-logic, where by this term I mean a mode of reasoning about infectious disease outbreaks that takes geographic particularities and similarities, continuities and discontinuities, as key aspects of the epidemiology of a particular disease; a mode of investigating outbreaks by asking geographic questions about their origin, course and outcome. The paper will begin by examining the application of this particular epidemiological rationality as originating in the research of a prominent French medical doctor, Jean-Jacques Matignon. It will then move to consider how it was consequently developed by the leading Russian plague-expert, Danilo Kirilovich Zabolotny, and how it reached its paradoxical conclusion with the work of another Russian researcher of plague, Ivan Stepanovich Dudchenko-Kolbasenko. The paper will argue that the latter's effort to bridge the geographic problematisation of plague with the tarbagan hypothesis was mediated by an epidemio-logical leap of faith: the acceptance on part of Dudchenko-Kolbasenko of the existence of man-eating marmots, and the constitution of this as an explanatory principle of plague outbreaks in the region.

\section{Matignon's expedition to Eastern Mongolia}

Jean-Jacques Matignon was born in Eynesse of Gironde in 1866. He graduated with a medical degree from Bordeaux in 1892 and was stationed in Beijing as an army doctor attached to the French Foreign Legation in 1895. Matignon was a prolific author on a wide array of medical issues in China, dwelling principally on exotic and sensational topics: Forbidden City eunuchs, "acromegalo-gigantism," foot-binding, Japanese mal-adaptability to Western boots, the Emperor Kangxi's "neuropathy," an alleged anti-leper pogrom in Nanjing, and a type of food poisoning, which he named atriplicism, inflicting North-Chinese beggars subsiding on an unwashed spinach-like herb. ${ }^{8}$ This medical-orientalist trajectory reached its apex in the publication of his magnum opus on Chinese "superstition, crime and poverty." 9 At the same time, however, Matignon was a practical man. He was active in the Peking Hospital as well as in medical expeditions to Manchuria, covering public health aspects of the Russian-Japanese War. ${ }^{10}$ Yet what sealed Matignon's international fame

as well as Hawaii. It must be kept in mind that none of the two major plague epidemics in Manchuria (1910-1911; 1920-1921) formed part of the third plague pandemic.

8. Anon. 1904; Anon. 1906; Anon. 1913; Matignon 1898a; Matignon 1913.

9. Matignon 1899a.

10. Anon. 1906. 
was his role as acting chief doctor of the Peking Foreign Legations during the Boxer siege of 1899-1900. ${ }^{11}$ All in all it may be said that by 1905 Matignon was the most recognised and admired French doctor operating in the Qing Empire.

It is not quite clear what first drew Matignon's attention north of the Great Chinese Wall, a topic perhaps best left to his future biographers. What is certain is that as soon as he arrived in the Far East, he engaged in research in Urga, the capital of Mongolia (then part of the Qing Empire), as well as in what he called Eastern Mongolia, an area currently forming part of Inner Mongolia. In the case of Urga, Matignon investigated courtly Mongolian medicine, whereas in the case of Eastern Mongolia his interest lay with the study of bubonic plague. The results of his Eastern Mongolian plague expedition were first presented to the French Academy of Sciences in December 1897 and published in an extensive article in the Annales d'hygiène et de médecine légale in 1898, republished a year later in the Archives de médecine et de pharmacie Militaires.

Matignon began his paper La Peste bubonique en Mongolie Orientale, by giving a brief account of the displacement of Mongols by the Chinese and their confinement in "the great plateaux of Mongolia." ${ }_{12}$ Describing the mountain ranges separating China from Mongolia, Matignon noted that the region, which was once covered in woods, now stood completely deforested as a result of the recent authorisation of Chinese migration by the Qing. Twelve days horse-ride away from Beijing to the northeast took Matignon to the valley of Sô-leu-kôn (Selenga) and the village of Toung-kia-Yng-tze, where "since nine years the bubonic reigns the plague." 13 Matignon wrote that the population of the valley was entirely Chinese: "the first colons consisted in Christians from the Manchurian border, who appealed to workers, mainly from the province of Shandon, to help them in their work of deforestation." ${ }^{14}$ These Shandong migrants were looked down upon by the French doctor as paragons of hygienic backwardness: "The hygienic conditions in which this population lives are most faulty [défectueuse]. The houses are filthy slums, real huts of savages, made of mud walls and thatched roof." ${ }^{15}$ Describing the structure of the huttes des sauvages in detail, Matignon stressed the role of the heated floor-bed commonly found in the region (kang, spelled by Matignon as kahn).

11. Matignon was in fact for a time believed to have perished during the siege (Anon. 1900b: 268).

12. Matignon 1899a: 463.

13. Matignon 1898: 228.

14. Matignon 1899a: 464.

15. Matignon 1898: 229. 
"Come winter," he wrote, "everything is carefully sealed and the air will not be renewed until the return of spring." ${ }^{16}$ Crowdedness in the local houses, and the tendency to keep sick members of the family indoors, alongside healthy individuals was seen as generating a "revolting bodily filth" hence providing "an excellent terrain" for the development of typhus, smallpox and trachoma (ophtalmie granuleuse). ${ }^{17}$ Matignon decried that nowhere else in China or Korea had he seen such "sordid people": "Most inhabitants wash their body but once a year. Soap is a thing absolutely unknown. The clothes are a block of dirt, worn for years, until they fall, somehow, in deliquescence." ${ }^{18}$ Moreover, he noted that the garments of those who died of "contagious disease are not disinfected nor washed and are worn by some member of the family of the deceased." ${ }^{19}$ As far as corpses were concerned, they were so carelessly buried that the first big rain brought them up to the surface. When it came to incidents of mass mortality, such as in the case of epidemics, Matignon claimed that corpses were simply thrown down a ravine nearby the village where they were devoured by wolves when the night fell. ${ }^{20}$

These conditions, Matignon argued, were ideal for the development of plague: "the habitats, houses, and soil are all receptacles in which Yersin's bacillus can easily wait for an opportunity to manifest its virulence." ${ }^{21} \mathrm{He}$ further claimed that to these general factors contributing to the spread of plague one should add a more particular one: once the disease appeared in a household, it was not only the parents who stayed in the house in constant contact with the sick, but also neighbours who visited, "passing the hour, talking, smoking [and] drinking in the chamber of the pest-inflicted [pestiféré]." ${ }^{22}$ Only after the epidemic reached great proportions, like in 1896, did fear force people to avoid patients. "Plague-pneumonia," as Matignon described the disease following medical conventions at the time, was seen as easily transported in the form of sputum sticking on clothes, shoes, and human hands: "I saw a man removing with his fingers from the mouth of his daughter sputum too sticky that it stuck to the teeth and lips. This accomplished, our man wiped his hands on his pants and after a while, without washing, began to eat." ${ }^{23}$

16. Matignon 1899a: 465.

17. Matignon 1899a: 465.

18. Matignon 1899a: 465.

19. Matignon 1899a: 465-466.

20. Matignon 1899a: 466.

21. Matignon 1898: 231.

22. Matignon 1899a: 466.

23. Matignon 1899a: 466. 
Plague, according to Matignon, first appeared in the village of Yan-che-kou, at the northwest of Toung-kia-Yng-tze in September 1888, when a twentyyear-old girl, who had never left the small valley, became the first victim of the disease. The pestilence, Matignon, noted, "seems to me to have been imported by the workers, who, every year, arriving in spring from the southern provinces, mainly that of Shandong, to help the natives in their work." ${ }^{24}$ Matignon noted that Shandong was not a foyer of plague, "yet the population of its coasts accounts for numerous sailors who work on cabotage in all the ports of the Chinese seas, going to Amoy and Canton, centres of plague, in transporting merchandise, clothes from all kinds of sources, where from many [people] may have fallen victim to plague. These clothes, purchased by workers, who go to Mongolia, have been used as a vehicle for germs of epidemic disease that seems now to have such strong roots in the valley of Sô-leu-kôn." ${ }^{25}$ Hence he proposed that plague was not native to Eastern Mongolia, but was rather imported there from South China on the backs of pestilent coolies. ${ }^{26}$

Matignon was interested in the geography of epidemics, and engaged in what Marta Hanson has called "visualisation of the geography of diseases." 27 His work was accompanied by two maps. One map traced the progress of plague in Selenga valley, in 1896 and $1897 .{ }^{28}$ In a fashion similar to the one sported by Emile Rocher in mapping the spread of plague in Yunnan twenty years earlier, Matignon drew arrows showing the imagined spread of plague between Eastern Mongolian villages over time. ${ }^{29}$ The second map provided a larger view of China, clearly demarcating Yunnan and the area around Canton as "centres of plague," with no equivalent "centre" in North China or beyond. Instead, the same map suggested that plague spread from Toung-kia-Yng-tze through Mongolia and Kyakhta (misspelled Kiarta) all the way to Irkutsk. This indicated that Matignon had probably come across literature on plague in Transbaikalia, although, in fact, no plague outbreak had been reported in the city of Irkutsk itself. Moreover it made clear that he considered Eastern Mongolia as a transit point, rather than as an endemic centre of the disease. ${ }^{30}$

24. Matignon 1898: 232.

25. Matignon 1898: 232. Shandong was spelled "Chan-toung" by Matignon, following the convention in both French and English at the time.

26. For a broader discussion on relating plague to coolies in China see Lynteris 2012.

27. Hanson 2011.

28. Matignon 1899a: 470.

29. Rocher 1879. Hanson (2012) has recently demonstrated that a year earlier Manson published the first map of the progress of plague in Yunnan.

30. For further discussion of Matignon's maps and mapping disease in China in general see Hanson (2012). 
Matignon was also interested in ethnography, and had already studied Mongolian courtly medicine, interviewing the Living Buddha's chief physician in Urga. ${ }^{31}$ In his famous "superstition" monograph, Matignon claimed that in the course of his plague expedition to Eastern Mongolia "serious people recounted that [the 1896] plague was brought by a black bull, every night, some times before the appearance of the first cases, between 9 and 10 o'clock, bellowing in a terrible manner, pouring fire from his eyes and nose, having descended in gallop from the Mongolian plateau to the Selenga valley." ${ }^{32}$ Matignon claimed that many natives said they had seen the animal with their own eyes, a belief shared by a Chinese priest "who despite practicing the Christian religion, was not totally stripped of Celestial superstition." ${ }^{33}$ The withering of the epidemic was said to be indigenously attributed to the appearance of two red-tunic Lamas walking alongside the Selenga River radiating a resplendent flame from their headgear. ${ }^{34}$

In spite of his keen ethnographic interest, Matignon made no mention whatsoever of marmots, let alone of their relation to plague..$^{35} \mathrm{He}$ nonetheless noted that, unlike in South China, no rat epizootic accompanied the epidemics, although a great number of flies seemed to be lying dead in the chambers of plague-inflicted patients. ${ }^{36} \mathrm{He}$ hence identified the disease as contagious: "A grave typhoid disease, almost always complicated by buboes, sometimes by expectorations similar to these of pneumonia, with very rapid development [and] fatal termination in 99 out of 100 cases: that is how Mongolian plague may be defined." ${ }^{37}$ Matignon was confronted with the classic diagnostic problem regarding pneumonic plague in the absence of bacteriological testing: a pneumonic condition resembling many other infections, with an erratic appearance of buboes, which were usually symptomatic in the first victim of the disease (developing first lymph and then lung infection), or, in rare cases, in patients suffering from pneumonic plague relapsing into bubonic form. In a stroke of medical insight, Matignon readily acknowledged this problem, and went on to provide some detailed case studies of plague, which he observed in the field. An advocate of drastic measures, he proposed that the only way of

31. Matignon 1895.

32. Matignon 1899b: 29.

33. Ibid.: 29

34. Ibid.: 30 .

35. In his earlier article on Mongolian medicine he only mentions marmots as a source of anti-dysmenorrhea medications amongst Mongols (Matignon 1895: 522).

36. Matignon 1899: 472.

37. Matignon 1899: 473. 
eradicating plague in the region was burning the Chinese migrant houses with all their possessions inside, as "their value is anyway minimal," warning, at the same time, that this being accomplished, graves would still pose a source of infection. ${ }^{38}$

Matignon reasoned that the limited needs of Selenga valley inhabitants "have so far been the best obstacle in the spread of plague. These Chinese seldom exit the valley, soil products being sufficient for their needs." 39 However, he feared that protracted contact with commercial centres could pose an international public health danger, with the disease spreading to Russia in the North through the large trading centre of Lama-miao, which was in direct communication with Kalgan, the main Chinese hub for tea and skin exports from China to Russia via Mongolia. "The day or the occasion when plague reaches Kalgan," Matignon reasoned, "Russia will be seriously menaced." 40 Hence Matignon saw Eastern Mongolia as a potential transfer node of bubonic plague from South China to Mongolia and Transbaikalia. In this sense we can say that, focused on the role of trade in spreading plague, Matignon followed the orthodox epidemiological problematisation of the infection during the third plague pandemic: he added next to the great plague-spreading harbours of the South (Hong Kong and Bombay) ${ }^{41}$ a continental sibling, which by means of caravan-led trade could spread the disease along the ancient tea and fur trading routes of Tartary.

\section{Matignon's international reception}

Matignon's study of plague in Eastern Mongolia had a significant impact on international plague literature at the time, as already evident a year later in the Twenty-Eighth Annual Report of Bruce Low, a highly influential medical officer of the British Empire. ${ }^{42}$ Low put emphasis on trade and dirt as factors in the generation and spread of the disease. As Robert Peckham has demonstrated in his recent work on the third plague pandemic, the two categories were intricately linked in Victorian imagination of pestilence, with the "conflated idiom of trade and plague functioning at once as metaphor, even as it reflected the practical challenges posed by potentially-contaminated

\footnotetext{
38. Matignon 1898: 250.

39. Matignon 1898: 481.

40. Matignon 1898: 481.

41. Echenberg 2007.

42. Low 1899.
} 
goods." ${ }^{43}$ Drawing on Matignon's report, Low stressed that these unhygienic subjects were not indigenous to the region but "a people who originally came from the province of Chang-Tong [Shandong], or the frontier of Manchuria"; roaming labourers who "occasionally go to So-len-ko Valley to assist in agricultural work." ${ }^{44}$ A crucial event validating Matignon's importation theory in the eyes of the British Colonial Office was the 1899 bubonic outbreak in the free harbour of Newchwang (Yingkou) in Southern Manchuria. ${ }^{45}$ The link was retrospective in so far as Matignon's findings came before rather than after the manifestation of plague in the Manchurian port; still, it appeared both logically and geographically evident from the perspective of the imagined pathogeny of "imperial interconnectedness." ${ }^{46}$

Medical journals were quick to report Matignon's findings. In May 1898 The British Medical Journal made brief note of his expedition, whilst two years later (August 1900) it returned to the subject, putting emphasis on the cramped and dirty Chinese dwelling conditions. The journal repeated Matignon's warning that "the new [plague] centre is a considerable menace to Russia, which has a large trade in tea and skins with Kalgan, which is quite near." ${ }^{47}$ The same year Matignon's findings were presented to the Englishspeaking medical public by a highly influential article to The Journal of Tropical Medicine authored by Franck G. Clemow. The paper was primarily a comprehensive review of Russian research on the tarbagan origins of plague in Transbaikalia, a hypothesis fully endorsed by Clemow, a very influential medical author for The British Medical Journal and The Lancet at the time. ${ }^{48}$ Hence Clemow was the first English-language author to bring Matignon's importation hypothesis face-to-face with the Russian tarbagan hypothesis. In an effort to balance the two theories and their mutually contradictory origin hypotheses, he argued for the existence of two epicentres of plague in what we now call Inner Asia. On the one hand, Transbaikalia, where the disease was

43. Peckham 2013: 4. Peckham notes Simpson's claim that the pathogen spread along the "most frequented trade routes" (Simpson 1902: 195; Peckham 2013: 11). Hence, he argues, Hong Kong was seen as a "disease hub" and plague as a "pseudo-commodity" (ibid: 13).

44. Low 1899: 124.

45. In this case too the openness of the harbour was seen as both source of wealth and death, with a special focus on the coolie labour force ( $c f$. Peckham 2013: 15). However, in the case of Newchwang, the connection between Shandong coolies and the Boxers complicated matters further, making this a political as well as economic threat.

46. On the notion of imperial interconnectedness, see Peckham 2013: 7.

47. Anon. 1898: 1286; Anon. 1900c: 454.

48. Clemow 1900. 
carried by marmots. And, on the other hand, Eastern Mongolia where plague appeared to have no such zoonotic link, as "if these animals take any share at all in the spread of the disease, they do so to an incomparably less extent than in the case of the Siberian disease." ${ }^{49}$ Clemow warned his readers that despite similarities, the two plague epicentres differed profoundly:

The Siberian centre is, apparently, in a flat steppe country; the Mongolian in a valley amongst hills, and at a considerable height above sea-level. In the former the disease occurs only in certain years, in the autumn, and solely from contact with infected tarbagans. In the latter it breaks out every year, in the summer, and quite independently [...] of disease in the lower animals. In the former it attacks only the members of the household of the first person affected, or others who have come into immediate contact with him or them, and each outbreak is thus limited to a clearly defined group of cases; in the latter it becomes epidemic over a considerable area, it is erratic in its course, it attacks a very large proportion of the entire community in a number of separate houses and separate villages, and there is no proof, apparently, that each fresh case is due to direct contact with a preceding case..$^{50}$

The keen plague-watcher did not overlook the possibility of a connection between the two plague zones, although his support of this scenario was so haphazard as to attract the indignation of an anonymous author in The British Medical Journal at the time. ${ }^{51}$ What is, however, truly perplexing is that although Matignon's famous report never once mentioned marmots, many authors tended to fuse Matignon's work with Beliavsky's tarbagan hypothesis.

A prime example of this is Louis Boucher's influential work on plague. In his 1901 address to the French Academy of Sciences at Rouen regarding a "permanent foyer" of plague, Boucher referred to the "so mysterious and so little explored" Central Asian plateau "among the populations of eastern Mongolia," which he described as "perhaps the poorest on the plane," where from "evil spreads to the north, in the region of lake Baikal, and to the south, in the mountain massif of Yunnam [sic] where it is definitively established." 52 This idea no doubt derived from a peculiar fusion of Matignon's research with the endemic hypothesis of Zabolotny (see below). Yet Boucher's major slight of hand was in claiming that Matignon's findings related to zoonosis, and the tarbagan in particular: "In these regions where poverty and uncleanliness [la

49. Clemow 1900: 173 .

50. Clemow 1900: 173-4.

51. Anon. 1900a: 540.

52. Boucher 1902: 136. 
misère et la malpropreté] are incredible, there exists a sort of rodent of the marmot family, the arctomys bobac or tarabagane [sic] whose role in the conservations and transmission of plague would be considerable." ${ }^{53}$

We cannot be certain about the source of this error, but a couple of possibilities appear more likely from a bibliographical perspective. The first scenario is that the confusion stemmed from a short appraisal of Matignon and his plague expedition by the future Nobel laureate Alphonse Laveran to the French Academy in 1900. ${ }^{54}$ The illustrious Academician acknowledged Matignon's contribution to the study of plague in Mongolia, whilst at the same time mentioning Russian studies on "tarabagan disease" in the area: "In 1897 Mr Matignon first noted the existence of foyers of plague in Mongolia, and his observations were confirmed by the Russian expedition for the study of plague." ${ }^{55}$ Though a careful reading of his address makes evident that Laveran never actually claimed marmots to figure in Matignon's work, the proximity of the two "outbreak narratives," in Wald's sense of the term, may have been the cause of the confusion at hand..$^{56}$ This is for example evident in Low's report on Laveran's appraisal of Matignon's work, where the British colonial medical officer clearly succumbs to this confusion of sources. ${ }^{57}$ An equally probable source is yet another short note, this time in the Dutch medical journal Janus, authored by Dr Stekoulis of Istanbul, another prolific but long-forgotten author on infectious diseases at the turn of the century. Stekoulis claimed that Matignon's expedition to Eastern Mongolia took place in response to an urgent call by Belgian missionaries operating in the region. ${ }^{58}$ The said fathers were supposedly alarmed by news about the Indian plague epidemic, realising that a disease they described as "tarbagan pest" amongst their flock may be no other than bubonic plague. ${ }^{59}$ How the Istanbulite Greek came to this conclusion is not clear, for whereas Matignon does mention the fathers briefly, he never claims that they were the ones who alarmed him to the existence of plague in the region, nor does he ever mentions marmots. It is likely that this anecdotal information was the source of future portrayals of Matignon as supporting the tarbagan hypothesis. Interestingly, Clemow further contributed to the

53. Boucher 1902: 152.

54. Laveran 1900: 155.

55. Laveran 1900: 155

56. Wald 2008.

57. Low 1901: 363; Low refers to Laveran's report as made by Matignon, adding to the confusion.

58. Stekoulis 1899: 617-618.

59. Stekoulis 1899: 617. 
confusion by claiming that it was Matignon who wrote the November 1899 Janus article. Hence the words of Stekoulis regarding the Belgian fathers were put in the mouth of Matignon. ${ }^{60}$

Whatever the case may be, the ripple effect of Matignon's research did not take long to reach St Petersburg, where in the spring of 1898 the newly founded Plague Commission decided to investigate matters further, by dispatching an expedition to Eastern Mongolia. Head of this fact-finding expedition on plague was one of the most prominent and charismatic epidemiologists in Russia at the turn of the century: Danilo Kirilovich Zabolotny.

\section{Zabolotny's expedition to Weichang}

Zabolotny (1866-1929) was a well-educated and progressive medical scientist from the Ukraine, who was expelled from the University of Odessa for student activism in 1889. Between 1896 and 1897, his participation in clinical and experimental research on plague in India during the great epidemic won him international repute. ${ }^{61}$ Besides Zabolotny, the expedition party comprised of Radnazhap Budaevich Bimbaev, Vladimir Taranoukhine, and a Cossack guide named Schiline. ${ }^{62}$ The team boarded the Trans-Siberian railway on June 4 1898, and then crossed the Mongolian border into Qing territory via Kyakhta, reaching Beijing on horseback after having crossed the Mongolian plateau. Following further arrangements in the imperial capital, Zabolotny and his team crossed the imperial hunting grounds of Weichang and reached Toung-kia-yng-tze, lying at the outskirts of the great woodlands. A summary of the original findings of the expedition was first published in Russian in the September 1899 issue of the Russian Archive of Pathology, Clinical Medicine and Biology, and, subsequently, in the November 1899 issue of the Annales de l'Institut Pasteur. ${ }^{63}$

Zabolotny described the village previously studied by Matignon as "not too big, but very populous. The Chinese houses, called 'phanses', are covered in straw; they are small, being composed of two rooms and contain generally speaking a family of 10 to 20 persons." 64 The doctor characterized the local population as Chinese, with a few Mongols who "spoke Chinese and already

\footnotetext{
60. Clemow 1900: 173.

61. Bilay 1966.

62. Bimbaev also provided his own account of the expedition (Bimbaev, 1899).

63. Zabolotny 1899a; Zabolotny 1899b; Zabolotny 1899c.

64. Zabolotny 1899c: 833.
} 
had Chinese mores." ${ }^{65}$ When it came to plague, Zabolotny alleged that "almost all the plague-inflicted were Catholics; hence, in frequenting each other, they have more chances of being contaminated than the pagans who avoid the sick." 66

Zabolotny was met by a group of missionaries (Zabolotny seemed unsure if they were Belgian or Dutch) led by father Léon Desmet, who provided "valuable information on the cases prior to our arrival, and on the current illness." ${ }^{\prime 77}$ According to the head of the mission, in the last dozen years the disease had been breaking out in the region annually in the summer months, having first made its appearance in Christian villages north of Selenga, not very far from Toung-kia-yng-tze. ${ }^{68}$ Father Léon claimed that in that year alone twenty-four people had been taken ill; all bore buboes or suffered from pneumonia, and all had succumbed to the scourge. Without delay Zabolotny set out to gather more information on the disease:

This is what we have learned. The epidemic has been known here for ten years now under the name of ven-i, ven-tszay, khai-ven; this was imported from North-East Mongolia. The Chinese consider the illness as incurable. They distinguish between two forms: the pulmonary form, whose gravest symptom is hemoptysis, and the bubonic form, which is characterised by the appearance of gada - the buboes. Entire families perish [of it]. When the Chinese perceive a bubo on someone in their family, they pinch, in the form of a treatment, the skin around the bubo. This forms ecchymoses which confer an appearance of marble on the patient's skin; some doctors have taken these spots for those of plague. In the pneumonic forms, they have the habit of covering with such form of artificial ecchymoses all the anterior part and the lateral parts of the thorax ${ }^{69}$

Zabolotny explained that there was no health service to aid people infected by the disease in the area, adding in a tone reminiscent of Matignon's treatises on superstition, as well as wider anti-Chinese prejudices in the West at the time: "The Chinese, fatalist by his nature, does not care about death. We may announce to him, without digression, that he will die tomorrow or even today, without these news having the power to impress him; he will merely thank

65. Zabolotny 1899c: 833.

66. Zabolotny 1899c: 833.

67. Zabolotny 1901: 65.

68. Zabolotny 1899c: 834.

69. Zabolotny 1901: 66. For a discussion of term wenyi as a generic term on epidemics, and notions of contagion in Imperial China see Hanson 2011; Leung 2011. 
you, meet his family so as to bid him farewell and share with them his last wishes." 70

Establishing an impromptu laboratory in the local church, Zabolotny was himself able to observe the disease in the case of a few individuals, starting with a thirty-year-old Chinese doctor who was taken ill on September 31898 at Maliento, a Chinese village near Toung-kia-yng-tze. Cultures developed from the ill man's bloody sputum appeared to contain plague bacilli. The patient died before twenty-four hours had elapsed from the first signs of fever. As performing an autopsy was culturally unthinkable, Zabolotny opted to procure liquid from the man's lungs, hence developing cultures that proved to contain plague bacilli, which once injected into animals (rats and mice) gave positive results. Zabolotny concluded his experiments by diagnosing "Pneumonia pestica." ${ }^{71} \mathrm{He}$ was also able to isolate plague bacilli from buboes of patients suffering from the bubonic form of the disease. ${ }^{72}$ Zabolonty's conclusion was unambiguous: "It is certain that we are here, in Eastern Mongolia, in presence of an endemic foyer of bubonic plague which, according to testimonies by missionaries and by doctor Matignon, has existed already for more than ten years." 73

Hence, whilst acknowledging Matignon's contribution in opening up the field of plague research in the region, Zabolotny was careful not to adopt his importation hypothesis. Claiming plague to be endemic, he sought to problematise the region as posing a threat to outlying territories: "the proximity of many great routes render this foyer excessively dangerous for China, as well as for Mongolia, Manchuria and, by consequence, Russia."74 It was at this point that, wondering about the origins of the disease, Zabolotny alerted his readers'attention to the existence of so-called tarbagan plague in Mongolia proper: "This disease is very contagious. The Buryats who feed on the tarbagans, without cooking them properly, take a disease that, according to the descriptions of Russian doctors, presents septicaemic characteristics, with

70. Zabolotny 1899b: 835. From a total of sixteen cases observed, six were pneumonic, eight bubonic and one septicaemic.

71. Zabolotny 1901: 68. Two more patients were similarly diagnosed whilst three were found to suffer from bubonic plague. It must be noted here that Zabolotny claimed it was easy to procure samples through injection of buboes due to the above-mentioned pinching custom. For a very different discussion of popular perceptions of injection in the region see Rogaski 2011.

72. Zabolotny 1899c: 836 .

73. Zabolotny $1899 \mathrm{c}: 837$.

74. Zabolotny 1899c: 837 , emphasis in the original. 
very violent fever, somnolence and tumefaction of the ganglions. This disease carries a very high mortality rate." 75

It is true that in the numerous articles deriving from the expedition, scarce mention is made of marmots or tarbagan plague, and yet Zabolotny did acknowledge the potentially important role of the particular rodents in transmitting plague amongst humans in the wider region. Two years later, in a longer article published in two installments in the Russian journal Archive of Biological Science, Zabolotny once again tacitly mentioned the tarbagan hypothesis, by reference to Beliavsky: "If we look at the presence of the endemic focus of plague in Mongolia, on the one hand, and on the other hand the cases of tarbagan plague previously described by Russian doctors and also observed in humans, we must conclude in favour of the identity of the tarbagan illness and true plague." 76

As Zabolotny is best known in medical history for his defense of the tarbagan origins of plague during the Manchurian epidemic of 1910-11, it is paramount to observe here his ambivalent position on this matter during the preceding decade. Although he clearly kept clear of Matignon's importation theory, his mind lingered between two alternative possibilities: plague stemming from tarbagan in Mongolia proper, and plague being actually endemic around Weichang in Eastern Mongolia. A map taking the larger part of a page at the end of his 1899 French article and also featured in his second paper to the Russian Archive of Pathology, Clinical Medicine and Biology the same year, portrayed regions believed by Zabolotny to be "hearths" (ochagi) of plague. ${ }^{77}$ The map was titled "Map of Endemic Hearths of Plague" and bore a handwritten note: "Note! Designated hearths where plague is bacteriological ascertained." 78 These included Assyria, Mesopotamia (with a question mark), Kisiba (in Tanzania), Tibet, Garhwal, Kumaon (both British Indian districts at the time), Yunnan, Canton, as well as a region designated with capital letters as Eastern Mongolia comprising of three localities: Weichang, "Toun-tsta-tuzu" and Khingan. Mongolia proper and Transbaikalia are absent from these shaded territories, whilst Eastern Mongolia is independent of the Southwest Chinese

75. Zabolotny 1899c: 837.

76. Zabolotny 1901: 74 .

77. Zabolotny 1899b: 243. The same map is reproduced identically in Zabolotny's 1899 pamphlet-size reprint of the second 1899 article (Zaboltny 1899d: 2), as well as in his 1907 monograph on plague (Zabolotny 1907: 6).

78. I would like to thank Susan D. Jones for bringing to my attention that ochag was rendered as "nidus" in the context of Eugene N. Pavlovsky's work on plague (1966). For a discussion of Pavlovsky's "landscape epidemiology," see Meade and Emch (2010). 
endemic zone. A second hand-drawn map portrayed the "Position of endemic hearths in Eastern Mongolia (Weichang region)." It showed Weichang in shaded grey with broken lines connecting it with towns all the way to Beijing and Tianjin in the south. A second broken line connected Beijing with Kalgan and, ultimately, Urga. ${ }^{79}$ The "geographic imagination" of plague fostered by Zabolotny was, we can say, multi-focal, and in this scheme of things Eastern Mongolia possessed a place next to other alleged international endemic zones of the disease. As we have already seen, this endemic hypothesis was adopted by international medical figures like Boucher, creating a third pole in the imagination of plague in the region.

It is hence evident that, already by 1900 , we have three distinct hypotheses regarding the origins of plague in Inner Asia: a) Beliavsky's tarbagan hypothesis, which claimed that plague is harboured by Siberian marmots, spreading to humans in Mongolia and Transbaikalia via blood-to-blood contact of the animal whilst harvesting its fat, meat and fur; b) Matignon's importation hypothesis, which claimed that plague is brought from South China to Eastern Mongolia by Shandong coolies employed in deforestation, and then, potentially spreading to Mongolia and Siberia via the tea and fur trade routes; c) Zabolotny's endemic hypothesis, which claimed that plague is permanently present in Eastern Mongolia; this hinted at a possible involvement of marmots but did not commit itself to either a zoonotic nor a human contagion link, leaving the question of pathogenesis open. The co-existence of these three distinct and implicitly contradictory hypotheses posed a serious problem to Russian plague experts, who were engaged in the systematic study of plague in Mongolia and Transbaikalia.

In the ten years preceding the 1910-1911 devastating pneumonic plague outbreak in Manchuria, which would render the question of the origins of the disease in the region a topic of international interest, no less than twenty original research papers on plague in Transbaikalia and Mongolia were published in the Russian medical press. Although Russian researchers largely sided with Beliavsky's tarbagan hypothesis, over the most part of the first decade of the twentieth century, the mystery of the role of the Eastern Mongolian foyer lingered as no Russian expedition was able to reach so far into Chinese territory after Zabolotny in order to re-examine the situation. The solution to this problem was to be given by the last major contributor to the study of plague in the region before the 1910-1911 Manchurian outbreak: Ivan Stepanovich Dudchenko, also known as Dudchenko-Kolbasenko.

79. Zabolotny 1907: 7. 


\section{Dudchenko's hybrid hypothesis}

Dudchenko was part of a Special Commission sent in 1908 to South Transbaikalia to investigate plague; he provided two major papers deriving from the expedition, which were to have a significant impact on medical perceptions of plague in the region.

Dudchenko was interested in examining the extent to which Zabolotny's theory on the Weichang origins of plague was contradicted by plague cases found in Mongolia and Transbaikalia. Key to his argument was the observation that the actual place where one finds plague-infected individuals should not be mistaken for the place where the disease originates. Dudchenko noted that the entire region under question was thick with major human traffic networks. From Buddhist pilgrims and tea-block traders, to Imperial envoys and Bannermen, anyone who wanted to reach Urga from Beijing and further afar had to pass via Zabolotny's plague zone: "It seems obvious that travelers from distant places, people weakened by road deprivation, with low natural resistance, can easily be infected with plague, driving slowly on camels across the plague focus, staying there for the night." ${ }^{80}$ Thus, a road-weary pilgrim or trader would stop at one of the villages near Weichang, contract the disease and thence travel into Mongolia carrying plague. So far, this hypothesis did not differ greatly from Zabolotny's speculations, or Matignon's fears. Yet at this point Dudchenko introduced a crucial link that would bridge it with the tarbagan hypothesis. Dudchenko argued that as the infected pilgrim or trader reached Mongolia, he or she would soon succumb to the disease and would be subjected, according to the Lamaist custom, to a sky burial. In other words, the plague-infected corpse would be exposed to the elements and any carrion caring to eat its flesh. What rendered this ethnographic speculation an exegetical tool in defining the trans-regional dynamics of plague was Dudchenko's claim that the sky burial of plague victims offered the opportunity to marmots to eat the infected corpses of unfortunate travelers and hence infect native hunters in turn. ${ }^{81}$

In support of this hybrid hypothesis, which was to fascinate epidemiologists for decades, Dudchenko offered further evidence in a short entry to the Russian Archive of Pathology, Clinical Medicine and Biology (November 1909). There he revealed information secured by a local vet, according to whom although plague afflicted humans in the region, marmots did not suffer from the disease, hence supposedly proving that rather than being the original hosts of plague, they were in fact but secondary victims of this human-derived disease.

80. Dudchenko-Kolbasenko, 1909b: 1048-1049.

81. Dudchenko-Kolbasenko 1909a: 1698. 
Dudchenko attributed the lack of marmot infection in the particular region to the fact that, as Muslims, the Kirgiz of the region in question buried corpses of plague victims rather than exposing them to sky burials like the Mongols:

The plague has not been apparently brought to the Akmolinsk District, but even if it was, it did not spread among marmot-tarbagan due to the burial customs of the Mohamedan Kirgiz who bury their dead underground and who therefore did not hitherto encounter this illness. It is known that dead bodies of the Mongols are left on the surface instead of burial, and that from plague-ridden corpses the plague is passed to the marmot-tarbagan as the latter devour dead bodies. ${ }^{82}$

This circular explanation of plague was crucial for Dudchenko as it elucidated why humans were infected by plague only in the late summer or early autumn. According to his calculations, this was the season when pilgrims and traders returned from their travels south by way of Weichang, thus first infecting marmots, which then infected humans in turn. ${ }^{83}$ Hence Dudchenko claimed that the reason why there were more frequent outbreaks in Mongolia than in Transbaikalia was not only because the former's proximity to Weichang but also because therein sky burial was religiously observed. By contrast, Transbaikalia was more distanced from the endemic focus of plague, and its population was also supposedly less observant of Tibetan Buddhist death rites. ${ }^{84}$

In order to illuminate this connection, Dudchenko published a map of this trans-regional infection route that warrants close examination..$^{85}$ The map, titled "Schematic Map: endemic hearths of plague in northern China and adjacent parts of southern Transbaikalia and northern Mongolia," featured two encircled regions: Weichang and the Mongol-Chinese border. The former bore in brackets the note "hearth [ochag] of endemic plague in North China," whilst the latter the note "hearth of endemic plague in south Transbaikalia and north Mongolia (tarbagan region)." Dudchenko drew two routes, both ending in Wutai, southwest of Beijing. The first crossed the western reaches of Weichang and ended up in Kubukhaevskay village, a few miles southeast of Aksha. The second crossed the eastern reaches of Weichang and ended up in Borzia, the major railway station before the Chinese border on the Chinese Eastern Railway line. Both trajectories were marked as "caravan routes," with arrows on the sides of the routes noting that the traffic (and perhaps the direction of

82. Dudchenko-Kolbasenko 1909a: 1699.

83. Dudchenko-Kolbasenko, 1909b: 1051.

84. Dudchenko-Kolbasenko, 1909b: 1078.

85. Dudchenko-Kolbasenko, 1909b: 1077. 
infection) was bilateral. It is not clear whether Wutai referred to the city or to the region of Wutaishan, but given that the latter was at the time a major Tibetan-Mongol Buddhist hub, it is likely that Dudchenko took the monastic complex for his reference. Wutaishan's significance as a pilgrimage destination for Mongols at the turn of the century has been recently studied by Isabelle Charleux, who has demonstrated that the particular religious practice was a process involving elites as well as ordinary Mongols. The pilgrims'motivation was karmic, therapeutic, and related to burying the bones of their parents in the holy land. Such goals did not exclude trade, which flourished in the monastic complex especially during the celebrated horse and mule fair on the sixth month of the Lunar year, coinciding with what Dudchenko considered as the peak of plague-spreading patterns in the region. ${ }^{86}$

We need to pay close attention to the importance placed on this Buddhist link for two reasons. First, because it reproduced the then dominant "outbreak narrative" connecting epidemics to pilgrimages in different parts of the globe. Second, because it contradicted the dominant Russian narrative regarding the relation between Tibetan-Mongolian Buddhism, known at the time as Lamaism, and plague, which contended that the particular form of Buddhism functioned as an inhibitor rather than as an amplifier of the disease in the region.

The Victorian imagination of pilgrimages as modes of transportation and sustenance of a wide array of infectious diseases is a topic that warrants sustained examination, which cannot be performed here. This attribution of pestilence was primarily connected with problematisations of the haj to Mecca as a conduit of infectious diseases ${ }^{87}$ In this wider context of epidemiological rationality, the problematisation of other pilgrimages operated within the boundaries of a global "geographic imagination" whose role was to connect different regions of the world nosologically ${ }^{88}$ Pilgrimage thus functioned as gravitational point of Victorian epidemiological rationality, in other words, as an epidemio-logical operator that allowed for the pathologisation of colonised (or semi-colonised) subjects'religious activities. ${ }^{89}$ In this respect, it is interesting to note that the Mongolian pilgrimage to Wutaishan was not the sole object of epidemiological problematisation in the region. Dr Levin, empowered by the Tsar to investigate the 1898 plague outbreak in Anzov

86. Charleux 2011. It is interesting to note here that there is no medical record of plague outbreaks in the monastic complex. Whether there are records of epidemics in the monastic archives themselves lies beyond the expertise of the author.

87. Bulmus 2012; Tagliacozzo 2013.

88. On the notion of nosology in the case of China, see Hanson 2012.

89. Arnold 1986. 
claimed "that this disease and the outbreaks of plague on the lower Volga and on the Caspian [...] might be due to carriage of infection from Mongolia by means of Kalmuck and Kirghiz pilgrims who might have visited certain sacred Moslem shrines in Mongolia, and brought the disease back with them." 90 In his influential book Geography of Epidemics, Clemow protested that distances between the two regions were impossibly vast, and that the Muslims "of the Kirghiz steppes east of the Volga are said to have no holy places of any kind in Mongolia, while the Kalmucks, who live to the west of the Volga, are despised and looked upon as heathens by both Mongols and Kirghiz and are not allowed to pass the Kirghiz steppes." 91

What differentiated the epidemiological problematisation of the Wutai pilgrimage was its place within the wider Russian medical literature on plague at the time, which proclaimed that Lamaism acted as an inhibitor to the spread of bubonic plague. This idea was first proposed by the eminent Polish physician, anthropologist and archaeologist Julian Talko-Hryntsewich who undertook a plague-related expedition to Mongolia in the autumn of 1899. In his much-quoted report to the bulletin of the Imperial Geographical Society's Kyakhta branch, he provided a rather confused narrative on native understandings of outbreaks in the region, which nonetheless hinted for the first time at a connection between the alleged native knowledge of plague (a constituent part of Beliavsky's tarbagan hypothesis) and the teachings of Lamaism. ${ }^{92}$ In particular, Talko-Hryntsewich claimed that the true source of plague was known to Mongols, as "it is said that ancient Buddhist religious laws forbid the consumption of the tarbagan and entering a temple wearing a fur coat [made from] that animal." 93 This information was, however, contradicted a few pages later when the anthropologist expressed serious reservations about Lamaist knowledge of plague in Mongolia. Interviewing a Lama on the disease, he admitted that the monk replied that it was a punishment sent by Burkhan (the Buddha) to sinners. Talko-Hryntsewich noted that the monk did not seem to understand the symptoms of the disease. This conclusion was seconded by a High-Lama, who claimed that the monks were so terrified of any disease that they would immediately flee from patients and refuse to treat them. Talko-Hryntsewich went on to claim that, in Urga, Lamas preached to Mongols that plague was the result of the spring lunar eclipse, and that the

90. Clemow 1903: 326.

91. Clemow 1903: 326.

92. On the 'native knowledge hypothesis'see Lynteris 2013.

93. Talko-Hryntsewich 1900: 100. 
disease would be particularly severe were the eclipse total. ${ }^{94}$ Overlooking the inherent contradiction in Talko-Hryntsewich's report, Russian plague experts sought to adopt the idea that Tibetan Buddhism endowed Mongols with a knowledge of plague. Hence in 1905, Dr Skrzhivan would write in the Russian Archive of Pathology, Clinical Medicine and Biology that knowledge of plague is evident in the writings of a certain Badmasambabor (evidently the lotus-born Padmasambhava), "who has foreseen the disease to come from soil to plants, from them to animals and then to people." ${ }^{95}$ Skrzhivan's long and muddled portrayal of Tibetan theories of disease was sprinkled with quasi-ethnographic elements and inspired fascination amongst international epidemiological circles for the next three decades. ${ }^{96}$

Dudchenko did not ignore nor repudiate this Buddhist connection. Instead, he engaged in further speculation about the alleged Lamaist knowledge of plague. What is rather striking is Dudchenko's apparent confusion on the matter. On the one hand, he noted that Buddhist monks who functioned as doctors in the region had no idea of contagion and thus spent entire days in the same yurt with patients - a fatal attitude in case of pneumonic plague, the most common clinical form of the disease in the region. ${ }^{97}$ And yet, at the same time, he seemed ready to forsake his skepticism and indulge in furthering the Lamaist connection as regards the native knowledge hypothesis, providing a story which would resonate in epidemiological writings for the years to come. He thus recounted that in October 1908 a Lama arrived at the monastery of Tosakh bringing news of a great epidemic that had devastated the encampment of Tsanid-Gegen in Ulyast, himself being the sole survivor. Following Dudchenko's narrative, "the Tosakh Lamas decided that the TsanidGegen and his men had died of plague," and decided to lock-up the monastery, letting no one in or out for thirty days: "Every day at a certain hour of the day all the inhabitants of the monastery came out into the open courtyard of the monastery and formed a line. Lamas of neighbouring datsans appeared at the same time on a nearby hill, and through binoculars accounted for all the people under quarantine, according to prearranged signals." 98 So successful was the "quarantine," that, in the words of Dudchenko, no one died in the "Tosakh joss-house."

94. Talko-Hryntsewich 1900: 101.

95. Skrzhivan 1905: 609.

96. Wu 1926.

97. Dudchenko-Kolbasenko 1909a: 1072.

98. Ibid.: 1076. 
What begs explanation at this point is how Dudchenko's appraisal of Lamaism as plague-preventative relates to his simultaneous condemnation of it as the very means through which the disease spread across Inner Asia. Clearly the crucial link here, the key to this epidemio-logical incoherence, is the mytheme of the man-eating Siberian marmots, in Lévi-Strauss's sense of the term, as the latent operator or constitutive element of Dudchenko's epidemiological rationality..$^{99}$

The outlandish idea that marmots eat human corpses should be sought in a chance encounter between a Russian epidemiologist, a human bone and a marmot hole. In 1900, Anatoly Podbel'sky organised a plague-finding expedition to Mongolia. There is no space here to do justice to the extensive and elaborate report of the doctor, published on December 301901 in the Russian Archive of Pathology, Clinical Medicine and Biology. What is crucial to our story is that, at the same time as conducting field observations on the tarbagan, Podbel'sky made another, rather accidental, discovery, which would assume its own life in epidemiological literature in the years to come:

Three yards from the exit hole was found a yellowed human tibial bone. Its epiphysis seemed to be broken off. Seven yards from the entrance of the burrow the ground was littered with the frontal and occipital bones of a human skull. The rest of the skeleton bones were not found. ${ }^{100}$

Podbel'sky risked no explanation of this discovery; he merely mentioned, half jokingly, that marmots are playful animals and may have used the bones for sharpening their mighty incisors. On a more sombre note, he also noted that one should not rule out the possibility of an infection from human corpses to Siberian marmots, in case the former had died of a "contagious disease, for example plague." ${ }^{101}$

This short passage would have been no more than a typical anecdotal entry in the chronicles of an expedition, and would have indeed remained a quaint footnote in the growing tarbagan literature if it was not for Georg Sticker who gave the story a whole new dimension. For in his Die Pest the influential German author re-invented the story, enriching it in a determining way. According to Sticker, the corpse was a plague victim, something Podbel'sky never asserted. ${ }^{102}$ Hence, readers of Die Pest were informed that, during sky

99. Lévi-Strauss 1955.

100. Podbel'sky 1901: 261

101. Podbel'sky 1901: 261

102. Sticker 1908: 123. 
burials, Mongols laid the bodies of the plague victims on the steppe where they were torn apart by carrion. As a result, their blood was said to soil the steppe grass so that marmots, which habitually fed on it, were infected. Adding more spice to his distorted and imaginative version of the original Russian paper, Sticker also added that tarbagan have the habit of dragging the bones of human plague victims into their nest, thus increasing the risk of infection. ${ }^{103}$

Seen from a critical anthropological perspective, we can say that the human tibial bone found by Podbel'sky near the marmot hole functioned as an epidemio-logical objet trouvé (found-object), in the surrealist tradition of the term. Or, if I may venture a bit further, as what the Rumanian surrealist poet and essayist Gherasim Luca called an "objectively offered object." An object that exercises a force of catalytic encounter upon the subject that comes across it, radically transforming his or her perception of the ordinary into an extraordinary perception. ${ }^{104}$ In the surrealist tradition, the objectively offered object allows different narratives and imaginaries to come together in a plane of consistency that does not represent either a synthesis of their theses or an overcoming of their antitheses. On the contrary the objectively offered object forces an anti-dialectical leap of faith: in our case, the belief in human-eating marmots, which, in the hands of Dudchenko, became the logical key to a new epidemiological discourse about the trans-regionality of plague.

Hence Dudchenko instituted a transformed "geographic imagination" of plague. This rejected both Matignon's hypothesis that the disease was imported from South China, and the original Russian tarbagan hypothesis, which argued that marmots were the original source of the disease. Accepting Zabolotny's thesis that Eastern Mongolia was an endemic focus of plague (but also adding Transbaikalia as a second endemic "hearth"), this geographic epidemiological model envisioned the crucial route of plague-importation to run not from South China to Weichang, but in a circuit between Wutai, Weichang, Mongolia and Transbaikalia. And, at the same time, it inverted the zoonotic link established by previous research, by claiming that it was humans who infected marmots rather than the other way around. Through an epidemio-logical leap of faith, a stratagem in epidemiological rationality - the endorsement of the mytheme of man-eating marmots-Dudchenko turned Beliavsky's tarbagan hypothesis on its head. The result was an apparently plausible if in fact surreal compromise between it, the endemic hypothesis of Zabolotny, and the trans-regional problematisation of plague transmission originally introduced by Matignon.

103. Sticker 1908: 123.

104. Luca 2009. 


\section{Conclusion}

What had started in 1898, in the hands of Jean-Jacques Matignon, as a standard exercise in explaining plague outbreaks in a backwater area of NorthEast China in terms of a trans-regional importation theory that pointed the finger at the alleged geographic source of the third plague pandemic (South China) and the usual suspects (Chinese coolies) was within little more than a decade transformed by Dudchenko into a complex "outbreak narrative" that bridged colonial-medical problematisations of pilgrimage, Russian Orientalist fascination with Tibetan-Mongolian Buddhism and research pointing at Siberian marmots as the zoonotic source of plague in Inner Asia.

The three geographic epidemiological assemblages described above would prove a vital index of concepts come the Manchurian pneumonic plague outbreak of 1910-1911. The Matignon-Zabolotny-Dudchenko trajectory would equip the "geographic imagination" of epidemics with a platform for negotiating the relation between zoonotic infection and human contagion, leading by April 1911 to another major reconfiguration of its three sites of problematisation: population movement, human-animal interaction, and endemicity. In a stroke of epidemio-logical genius, Wu Liande, the leader of Chinese anti-plague efforts in Manchuria, would recombine these elements in a plausible form, convincing the international medical community that plague was endemic in Transbaikalia, that it was a disease of the tarbagan transmitted to humans whilst hunting the animal, which, turning pneumonic and airborne, was thence carried south by Chinese coolies. ${ }^{105}$

Rather than signaling the demise of more adventurous explanations (including man-eating marmots) in epidemiological literature, Wu's model would become a canonical exegesis against which such elements, as well as new problematisations of the geographic and zoonotic aspects of plague in the region, would be evaluated. The controversial role of $\mathrm{Wu}$ as an epistemological referee in this process is beyond the scope of this paper, yet it is important to keep in mind, in terms of a concluding methodological precaution, that medical historians as well as epidemiologists should be particularly weary of relying on Wu's synthesis of previous plague research in the region. As shown in this paper, the history of plague research and theory in Manchuria and Inner Asia was a far more multivocal, innovative and contradictory process than the linear narrative of scientific discovery retrospectively procured in the writings of the self-styled "plague fighter." 106

105. Strong 1912; Wu 1926.

106. Wu 1956. 
Jean-Jacques Matignon's Legacy on Russian Plague Research

\begin{tabular}{|l|l|l|l|l|}
\hline & Infection Route & $\begin{array}{l}\text { Endemic } \\
\text { Hearth }\end{array}$ & $\begin{array}{l}\text { Geographic } \\
\text { Route of } \\
\text { Contagion }\end{array}$ & $\begin{array}{l}\text { Mode of Infection/ } \\
\text { Contagion }\end{array}$ \\
\hline $\begin{array}{l}\text { Beliavsky } \\
\mathbf{1 8 9 4}\end{array}$ & $\begin{array}{l}\text { tarbagan to humans } \\
\text { to humans }\end{array}$ & $?$ & $?$ & hunting (I) \\
\hline $\begin{array}{l}\text { Matignon } \\
\mathbf{1 8 9 8}\end{array}$ & humans to humans & South China & $\begin{array}{l}\text { South China to } \\
\text { Eastern Mongolia } \\
\text { (to Mongolia/ } \\
\text { Transbaikalia?) }\end{array}$ & trade \& dirt (C) \\
\hline $\begin{array}{l}\text { Zabolotny } \\
\mathbf{1 8 9 9}\end{array}$ & $\begin{array}{l}\text { tarbagan to humans/ } \\
\text { humans to humans }\end{array}$ & Weichang & $\begin{array}{l}\text { Weichang to } \\
\text { Beijing (to } \\
\text { Mongolia?) }\end{array}$ & $\begin{array}{l}\text { hunting (I) \& } \\
\text { human contact (C) }\end{array}$ \\
\hline $\begin{array}{l}\text { Dudchenko } \\
\mathbf{1 9 0 9}\end{array}$ & $\begin{array}{l}\text { humans to tarbagan } \\
\text { to humans }\end{array}$ & $\begin{array}{l}\text { Weichang } \\
\text { \&Transbaikalia/ } \\
\text { Mongolia }\end{array}$ & $\begin{array}{l}\text { Circuit between } \\
\text { Wutai, Weichang, } \\
\text { Mongolia and } \\
\text { Transbaikalia }\end{array}$ & $\begin{array}{l}\text { pilgrimage (C) } \\
\text { \&sky burial (I) } \\
\text { \&hunting (I) }\end{array}$ \\
\hline $\begin{array}{l}\text { Wu Liande } \\
\mathbf{1 9 1 1}\end{array}$ & $\begin{array}{l}\text { tarbagan to humans } \\
\text { to humans }\end{array}$ & $\begin{array}{l}\text { Transbaikalia/ } \\
\text { Mongolia }\end{array}$ & $\begin{array}{l}\text { Transbaikalia to } \\
\text { China }\end{array}$ & $\begin{array}{l}\text { hunting (I) \& } \\
\text { “floating } \\
\text { population" (C) }\end{array}$ \\
\hline
\end{tabular}

Theories of Plague Transmission in North-East China and Inner Asia

\section{Acknowledgements}

Research leading to this paper was conducted under an Andrew Mellon and Isaac Newton Interdisciplinary Postdoctoral Research Fellowship at the Centre for Research in the Arts, Social Sciences and Humanities (CRASSH) of the University of Cambridge and was also generously supported by a Cambridge Humanities Research Grant. I would like to thank the staff of the Russian State Library and Dr Valentina Kharitonova, director of the Medical Anthropology Group of the Institute of Ethnology and Anthropology of the Russian Academy of Sciences for their support during my research in Moscow. 


\section{BIBLIOGRAPHY}

Anonymous (1898). “The Bubonic Plague in Manchuria.” The British Medical Journal, vol. 1, iss. 2735: 1286.

Anonymous (1900a). "The Plague, Progress of the Disease: Siberia." The British Medical Journal, vol. 1, iss. 2044: 540.

Anonymous (1900b). "Obituary." The British Medical Journal, vol. 2, iss. 2065: 268

Anonymous (1900c). "Chinese Imperial Maritime Customs." The British Medical Journal, vol. 2, iss. 2068: 453-454.

Anonymous (1904). “The Japanese Soldier's Feet.” The British Medical Journal, vol. 1, no. 2263: 1150-1151.

Anonymous (1906) “The Disinfection of an Army.” The British Medical Journal, vol. 2, iss. 2391: 1148.

Anonymous (1913). “A Short Way with Lepers.” The British Medical Journal, vol. 1, iss. 2735: 1181.

Arnold David. (1986). "Cholera and Colonialism in British India." Past and Present, 113 (1): 118-151.

Beliavsky Mikhail. E. (1895). “O Chumê Tarbaganov: Zapika po Povodu 7 Cmertnuikh Sluchaev ot Upotrblenïya v Pishchu Surkov, Porazhennuikh Chumoyu v Pocelkê Soktuevskom (On Tarbagan Plague: note about 7 deaths from eating marmots

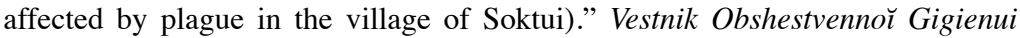
Sudebnŏ i Praktichesnŏ Meditsinui (Khronika, Izvêstiya i Smês), vol. 23, no. 2: $1-6$.

Bimbaev Radnazhap Budaevich (1899). “Zamêtki o Chumnoŭ Ekspeditsiï v Vostochnuyu Mongolii v $1898 \mathrm{G}$ (Notes on the Plague Expedition in Eastern Mongolia in 1898)." Tudui Troichkoskago-Kyakhtinskago Otdeleniya Priamurskago Otdela Imperatorskago Russkago Geograficheskago Obshchestva, vol. 2, no. 1-2: 31-44.

BILAY V.I. (1966). Zhizn'Otdannaya Lyudyam: K 100 Letiyu so Dnya Rozhenniya D. K. Zabolotnogo (Life Devoted to the People: on the 100th anniversary from the birth of D. K. Zabolotny). Kiev, Izdatel'stvo Naukova Dumka.

Boucher Louis M. (1902). "La peste à la fin du XIX et au XX⿳亠丷厂 siècle." Précis analytique des travaux de l'Academie des Sciences, Belles-Lettres et Arts de Rouen pendant l'année 1900-1901. Rouen, Caniard.

Bulmus Birsen (2012). Plague, Quarantine and Geopolitics in the Ottoman Empire. Edinburgh, Edinburgh University Press.

Clemow Franck G. (1903). The Geography of Disease. Cambridge, Cambridge University Press.

DudchenKo-Kolbasenko Ivan. S. (1909). “K Voprosu o 'Tarbagan'eĭ Chumê (On the

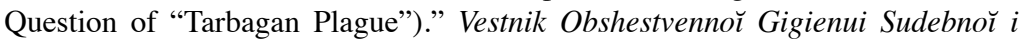
Praktichesno ̌ Meditsinui, vol. 45, no. 11 (November 1909): 1698-1699.

DudChENKo-KolbasenKo Ivan. S. (1909). "Ob Izslêdovaniii Chumnuikh Zabolêvaniĩ v Zabaykaŭl'skoŭ Oblasti v 1908 Godu v Svyazi s Tarabagan'eř Chumor̆ (On the Study of Pestilential Diseases in the Transbaikal Oblast in 1908 in Connection with 


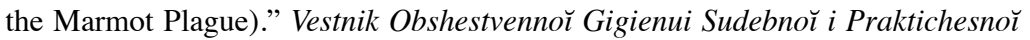
Meditsinui, vol. 45, no. 6 (June 1909): 897-909.

Echenberg Myron J. (2007). Plague Ports: The Global Urban Impact of Bubonic Plague. 1894-1901. New York, New York University Press.

Gamsa Mark (2006). "The Epidemic of Pneumonic Plague in Manchuria 1910-1911.” Past \& Present, vol. 190: 147-184.

Golubev Gleb. (1962). Zitniye Danila Zabolotnogo. Moscow, Molodaya Gvardiya.

Hanson Marta E. (2011). Speaking of Epidemics in Chinese Medicine: Disease and Geographic Imagination in Late Imperial China. London, Routledge.

Hanson Marta E. (2012). "Visualizing the Geography of Diseases in China. 1870s-1920s". Paper given at the Ohio State University Center for Historical Research Program for 2011-2012 Health, Disease, and Environment in World History.

KnAB Cornelia. (2011). "Plague Times: Scientific Internationalism and the Manchurian Plague of 1910/1911." Itinerario, vol. 35, no. 3: 87-105.

Laveran Alphonse (1900). "Untitled." Bulletin de l'Academie de Medicine, Serie 3, vol. 43 (Séance du 20 Fevrier 1900): 155.

LEI Sean Hsiang-lin (2011). "Sovereignty and the Microscope: Constituting Notifiable Infectious Disease and Containing the Manchurian Plague (1910-11)". In Angela Kiche Leung and Charlotte Furth (eds.), Health and Hygiene in Chinese East Asia: Policies and Publics in the Long Twentieth Century. Durham, Duke University Press: 73-106.

Leung Angela Ki Che A. (2011). "The Evolution of the Idea of Chuanran Contagion in Imperial China." In Leung, Angela Kiche and Charlogtte Furth (eds.), Health and Hygiene in Chinese East Asia: Policies and Publics in the Long Twentieth Century. Durham, Duke University Press.

LÉvi-STRAuss Claude (1955). "The Structural Study of Myth.” The Journal of American Folklore, vol. 68, no. 270, "Myth: A Symposium": 428-444.

Low Robert Bruce. (1899). "Report Upon the Progress and Diffusion of Bubonic Plague from 1879 to 1898 (Appendix A, no. 18).” Twenty-Eighth Annual Report of the Local Government Board, 1898-1899, with Supplement Containing the Report of the Medical Officer for 1898-99 [C.9445]: 199-258.

Low Robert Bruce (1902). Reports and Papers on Bubonic Plague with Introduction by the Medical Officer of the Local Government Board (Session 1901), [Cd. 748].

LuCa Gherasim (2009). The Passive Vampire. Prague: Twisted Spoon.

LyNTERIS Christos (2013). "Skilled Natives, Inept Coolies: Marmot Hunting and the Great Manchurian Pneumonic Plague (1910-1911).” History and Anthropology, vol. 24, no. 3 (August 2012): 303-321.

Matignon Jean-Jacques (1895). "La Médecine des Mongols." Archives cliniques de Bordeaux, vol. 4, no. 11: 515-523.

MATIGNON Jean-Jacques (1898a). "De l'atriplicisme (intoxication par l'Arroche)." China Imperial Maritime Customs Medical Reports, 54th issue, Shanghai.

Matignon Jean-Jacques (1898b). "La peste bubonique en Mongolie.” Annales d'hygiène publique et de médecine légale, Serie 3d, 39: 227-256. 


\section{Christos Lynteris}

Matignon Jean-Jacques (1899a). "La peste bubonique en Mongolie." Archives deMédecine et de Pharmacie Militaires, vol. 33: 463-486.

Matignon Jean-Jacques (1899b). Superstition, crime et misère en Chine (souvenirs de biologie sociale). Paris, Masson et cie.

Matignon Jean-Jacques (1913). "La Destruction des Centres Lépreux en Chine." La Chronique Medicale, vol. 20, no. 10: 289-291.

Meade Melinda S., Emсн Michael (2010). Medical Geography. New York, The Guilford Press.

Peckham Robert (2013). "Infective Economies: Empire, Panic and the Business of Disease." The Journal of Imperial and Commonwealth History, vol. 41, no. 2: 213-237.

Pavlovsky Eugene. N (1966). Natural Nidality of Transmissible Diseases. Chicago, University of Illinois Press.

PodBel'sky Anatoly I. (1901). “Nablyudeniï nad Tarbaganami v Mongolïi (Observations on the Tarbagan in Mongolia)." Russĭ̌ Arkhiv Patalogï, Klinicheskŏ Meditsinui i Baketeriologï: 249-265.

Rocher Émile (1879). La Province Chinoise du Yunnan. Paris, Lerous, 1879.

Skrzhivan F. (1900). "Nashi Svêdênïya o Tarabagan'eï Chumê (Our Data on Tarbagan Plague).” Russiŭ Arkhiv Patalogï, Klinicheskŏ Meditsinui i Baketeriologii: 603612 .

Stekoulis (1899). "Contribution à l'étude de la peste de Mongolie." Janus. Archives internationales de l'histoire de la médecine et la géographie médicale, vol. 4: 617-618.

Simpson William. J. (1905). Treatise on Plague: Dealing with the Historical, Epidemiological, Clinical, Therapeutic and Preventive Aspects of the Disease. Cambridge, Cambridge University Press.

STICKER Georg (1908). Abhandlungen aus der Seuchengeschichte und Seuchenlehre, 2 vols. (Gießen: Töpelmann, 1908), vol. 1 ("Die Pest als Seuche und als Plage").

Strong Richard. P. (ed.) (1912) Report of the International Plague Conference (held at Mukden in April 1911). Manila, Bureau of Printing.

Summers William C. (2012). The Great Manchurian Plague of 1910-1911: The Geopolitics of an Epidemic Disease. New Haven, Yale University Press.

Talko-Hryncewicz Julian. D. (1899). "O Chumnuikh Zabolêvanïyakh v Mongoliii (On Pestilential Diseases in Mongolia).” Trudui Troichkoskago-Kyakhtinskago Otdeleniya Priamurskago Otdela Imperatorskago Russkago Geograficheskago Obshchestva, vol. 1, no. 1-2: 96-110.

Tagliacozzo Eric (2013). The Longest Journey: Southeast Asians and the Pilgrimage to Mecca. Oxford, Oxford University Press.

Wald Priscilla (2008). Contagious: Cultures, Carriers, and the Outbreak Narrative. Durham, Duke University Press.

Wu Liande (1926). Treatise on Pneumonic Plague. Geneva, League of Nations.

Wu Liande (1956) Plague Fighter: The Autobiography of a Modern Chinese Physician. Cambridge, Heffers. 
Zabolotny Danilo K. (1899a). "Pustulezna Forma Chumui (Pustular Form of Plague)." Russĭ Arkhiv Patalogï, Klinicheskoŭ Meditsinui i Baketeriologï: 239-241.

Zabolotny Danilo K. (1899b). "Epidemicheskïe Ochagi Chumnui na Zemnom Share

i Prichinui eya Rasprostranenïya (Epidemic Foci of Plague on the Globe and the Reason for its Spread)." Russï̈ Arkhiv Patalogï, Klinicheskŏ Meditsinui $i$ Baketeriologii: 242-250.

Zabolotny Danilo K. (1899c). “La Peste en Mongolie Orientale.” Annales de l'Institut Pasteur, vol. 13, no. 11: 833-840.

Zabolotny Danilo K. (1899d). Epidemicheskie Ochagi Chumnui na Zemnom Share $i$ Prichinui eya Rasprostranenïya. St Petersburg, K. L. Rikker.

Zabolotny Danilo K. (1901). “Izcledovanïya po Chumê; Stat' ya Pervaya (Research on Plague; first article).” Arkhiv Biologicheskikh Nauk, vol. 8, no. 1: 59-77.

Zabolotny Danilo K. (1907). Chuma (Pestis bubonica) Epidemiologia, Patogenez $i$ Profilaktika (Plague Epidemiology, Pathogenesis and Prevention). St Petersburg, Interior Ministry Press. 